\title{
A generic plant RNA isolation method suitable for RNA-Seq and suppression subtractive hybridization
}

\author{
Y.Q. Zhu ${ }^{1,2}$, W.J. Wu ${ }^{1,2}$, H.W. Xiao, ${ }^{1,2}$, H.B. Chen ${ }^{1,2}$, Y. Zheng ${ }^{1,2}$, \\ Y.J. Zhang' ${ }^{2}$ H.X.Wang ${ }^{2}$ and L.Q. Huang, \\ ${ }^{1}$ School of Life Sciences, Tsinghua University, Beijing, China \\ ${ }^{2}$ The Shenzhen Key Laboratory of Gene and Antibody Therapy, \\ Center for Biotech and BioMedicine, \\ State Key Laboratary of Health Sciences and Technology, \\ Division of Life and Health Sciences, Graduate School at Shenzhen, \\ Tsinghua University, Shenzhen, Guangdong, China \\ Corresponding author: L.Q. Huang \\ E-mail: huanglq@sz.tsinghua.edu.cn
}

Genet. Mol. Res. 12 (4): 5537-5546 (2013)

Received September 13, 2012

Accepted February 5, 2013

Published November 18, 2013

DOI http://dx.doi.org/10.4238/2013.November.18.4

\begin{abstract}
A recently developed revolutionary approach to transcriptomics, RNA-Seq, and suppression subtractive hybridization are powerful tools for gene expression research. However, currently, the difficulty of isolating high-quality RNAs from plant tissues bearing abundant complex polysaccharides, polyphenolics, and secondary metabolites is a serious problem that not only limits the application of these technologies but also hinders studies dealing with RNA in general. We have developed a consistent protocol to prepare highly intact and pure RNAs from tissues of a variety of field-grown plant species, with high yields, in 2 to $3 \mathrm{~h}$. Additionally, this method can be readily applied to mammalian, yeast, and bacterial cells.
\end{abstract}

Key words: Plant RNA; Isolation; Polyphenols; Polysaccharides; RNA-Seq 


\section{INTRODUCTION}

Identifying differentially expressed genes and comparing their expression patterns are important to deciphering their functions relevant to evolution, differentiation, and development. Sequence- or hybridization-based approaches including RNA-Seq, cDNA array, and suppression subtractive hybridization (SSH) have been employed to analyze transcriptomes. RNASeq, utilizing recently developed deep-sequencing technologies, provides researchers with a genome-scale transcription map that consists of the transcriptional structure and precise levels of transcripts. On the other hand, hybridization-based SSH is also a powerful technique for identifying differentially expressed genes. For these technologies, obtaining abundant, intact, pure, and consistent RNAs is a basic prerequisite. Unfortunately, extracting plant RNA is a very tedious and challenging task, primarily because of the polysaccharides and polyphenolics that irreversibly interact and co-precipitate with nucleic acids (Katterman and Shattuck, 1983; Levi et al., 1992; Gehrig et al., 2000). Moreover, plants have complex metabolic pathways through which a great number of various secondary metabolites are generated. The enormous compositional differences among plants also profoundly influence the ribonucleic acids preparation procedures (Loomis, 1974; Sharma et al., 2003). Because of a plant's "chemotypic heterogeneity," it is believed that even closely related plant species might require different nucleic acids isolation protocols, and just one method that is suitable for all plant species would never be developed (Loomis, 1974; Weishing et al., 1995; Sharma et al., 2003).

The common methods for plant RNA isolation published so far are mainly based on the following approaches: guanidinium/guanidine salts (Puissant and Houdebine, 1990; Chomczynski and Sacchi, 1987, 2006) or urea (Almarza et al., 2006); acid phenol (Geuna et al., 1998); detergents like cetyl trimethyl ammonium bromide (CTAB) (Chang et al., 1993; Ildiko et al., 1999; Kiefer et al., 2000) and sodium dodecyl sulfate (Newbury and Possingham, 1977; Wan and Wilkins, 1994). These protocols, including the commonly used commercial kits (Qiagen RNeasy Plant Kit, Invitrogen TRIzol Reagent, and Ambion RNAqueous Kit), may be suitable for particular plant species and tissues. However, when applied to untested materials, these protocols usually need some adjustments, and, even after improvement, they may not work well, all because of the "chemotypic heterogeneity" problem (Khanuja et al., 1999; Li et al., 2006).

We describe here a procedure that we have developed for the isolation of plant RNA, which combines and incorporates the advantages of several reported methods. It was tested and validated by applying to tissues from 18 plant families (5 field-grown woody plant families, 13 herbaceous plant families), mammalian Hela cells, and Escherichia coli DH5 $\alpha$ and yeast Saccharomyces cerivisiae Y190 cells. The quality of the isolated RNAs was consistently high, as judged by spectrophotometric readings, the formaldehyde denaturing agarose gel separation analysis, and the Agilent Bioanalyzer NanoDrop assay. Furthermore, the RNA samples yielded fine results when used for mRNA extraction, double-stranded (ds) cDNA synthesis, 3' cDNA ends amplification, reverse transcription polymerase chain reaction (RT-PCR), RNA-Seq, and SSH.

\section{MATERIAL AND METHODS}

\section{Plant and cell materials}

The field-grown plant tissues were harvested from University Town of Shenzhen Gar- 
den, or purchased as indicated (Table 1). Mid-exponential phase E. coli DH5 $\alpha$ and S. cerivisiae Y190 cells cultured in liquid medium were collected by centrifugation, respectively. All plant tissues, yeast, and bacterial cells were thoroughly ground into fine powders, under liquid nitrogen, using a mortar and pestle. The ground samples were stored at $-80^{\circ} \mathrm{C}$ for future use. Confluent HeLa cells $(80 \%)$ in a $5 \times 5 \mathrm{~cm}$ flask were digested with trypsin, collected by centrifugation, and directly lysed with a homogenization solution at room temperature.

\section{Solutions and reagents}

Homogenization solution: 2\% CTAB (w/v); $1.5 \mathrm{M} \mathrm{NaCl} ; 100 \mathrm{mM}$ Tris, $20 \mathrm{mM}$ EDTA, $\mathrm{pH} 8.0$; and $2 \% \beta$-mercaptoethanol [ $(\mathrm{v} / \mathrm{v})$; added before use]. Precipitation buffer: $10 \mathrm{M}$ lithium chloride ( $\mathrm{LiCl})$. Denaturing solution: $4.0 \mathrm{M}$ guanidinium thiocyanate; $25 \mathrm{mM}$ sodium citrate, $\mathrm{pH} 7.0 ; 0.5 \%$ sodium N-lauroyl sarcosine $(\mathrm{w} / \mathrm{v})$; and $2 \% \beta$-mercaptoethanol $[(\mathrm{v} / \mathrm{v})$; added before use]. Organic reagents: water-saturated phenol/chloroform [1:1 (v/v), pH 4.5]; chloroform; absolute ethanol, and 75\% ethanol.

\section{RNA isolation protocol}

Preheat $2.5 \mathrm{~mL}$ homogenization solution contained in a $10 \mathrm{~mL}$ tube at $65^{\circ} \mathrm{C}$ for $3 \mathrm{~min}$. Transfer approximately $500 \mathrm{mg}$ frozen tissue powder into the tube, vigorously shake the tube, and then incubate it at $65^{\circ} \mathrm{C}$ for 3 to $5 \mathrm{~min}$. Spin the tube in a microcentrifuge at $14,000 \mathrm{rpm}$ for $2 \mathrm{~min}$ at room temperature. Transfer the supernatant to two fresh microcentrifuge tubes.

Add 0.1 volume of $10 \mathrm{M} \mathrm{LiCl}$ to the supernatant. Invert the tube several times and incubate it at $-20^{\circ} \mathrm{C}$ for 15 to $20 \mathrm{~min}$, or go directly to the next step without incubation. Centrifuge the liquid in a microcentrifuge at 12,000 to $14,000 \mathrm{rpm}$ for $30 \mathrm{~min}$ at $4^{\circ} \mathrm{C}$ to pellet the RNA. Discard the supernatant completely and suspend the pellet in 100 to $200 \mu \mathrm{L}$ denaturing solution.

Add an equal volume of water-saturated phenol/chloroform [1:1 (v/v), $\mathrm{pH} 4.5]$. Vortex the tube and then spin it at $12,000 \mathrm{rpm}$ for $5 \mathrm{~min}$ at $4^{\circ} \mathrm{C}$. While avoiding disturbing the interphase, transfer the aqueous phase into a fresh tube. Add an equal volume of chloroform, and then vortex and spin the tube at $12,000 \mathrm{rpm}$ for $1 \mathrm{~min}$ at $4^{\circ} \mathrm{C}$. For most of the samples listed in Table 1, the organic extraction could be omitted. The RNAs qualitiy was almost as good as these organic extraction-treated RNAs (data not shown).

Transfer the supernatant to a fresh microcentrifuge tube, add 2.5 volumes of $100 \%$ ethanol, and then vortex and centrifuge at maximum speed for $15 \mathrm{~min}$ at $4^{\circ} \mathrm{C}$. The RNA pellet at this stage could be stored at $-80^{\circ} \mathrm{C}$ for several months (data not shown).

Discard the supernatant, wash the pellet with $0.5 \mathrm{~mL} 75 \%$ ethanol, and then spin the tube at $8000 \mathrm{rpm}$ for $3 \mathrm{~min}$ at room temperature. Repeat this step twice. Decant the supernatant, spin briefly, and collect and aspirate the residual supernatant. Air-dry the pellet at room temperature and dissolve it in diethylpyrocarbonate-treated water.

\section{Estimation of RNA quality}

\section{$R N A$ purity, integrity, and yield analyses}

The RNA purity and quantity were assessed spectrophotometrically at wavelengths 
of 230,260 , and $280 \mathrm{~nm}$. The RNA integrity was verified by analyzing 4 to $8 \mu \mathrm{g}$ RNA via $1 \%$ formaldehyde (w/v) denaturing 1.2\% agarose gel electrophoresis (Sambrook et al., 1989) and 1 to 5ng RNA via the NanoDrop test with the Agilent 2100.

\section{RT-PCR}

Total RNA $(2 \mu \mathrm{g})$ extracted from the young shoot tip and young leaf of mango (Mangifera indica L.) was reverse transcribed using the Moloney murine leukemia virus reverse transcriptase (M-MLV) $\mathrm{RNase} \mathrm{H}^{-}(\mathrm{TaKaRa})$ with the oligo(dT) ${ }_{18}$ primer. Using the psbA gene-specific 5' primer (5'-ATGACTGCAATTTTAGAGAGA-3') and 3' primer (5'-TTATCCATTTATAGATGGAGC-3'), and the Actin 1 gene-specific $5^{\prime}$ primer (5'-GTGACAATGGAACTGGAATG-3') and 3' primer (5'-AGACGGAGGATAGCGTGAGG $\left.-3^{\prime}\right)$, subsequent PCRs were carried out with Taq DNA polymerase (TaKaRa). The PCR conditions were as follows: $94^{\circ} \mathrm{C}$ for $2 \mathrm{~min}, 35$ cycles of $94^{\circ} \mathrm{C}$ for $30 \mathrm{~s}, 55^{\circ} \mathrm{C}$ for $30 \mathrm{~s}$, and $72^{\circ} \mathrm{C}$ for $45 \mathrm{~s}$; and a final cycle of $72^{\circ} \mathrm{C}$ for $7 \mathrm{~min}$.

\section{3'-cDNA ends amplification}

In order to amplify the 3 '-cDNA ends of gene Actin1, a specific 5' primer and an anchor 3' primer (5'-TTTTTTTTTTTA-3') were used for the PCR. The thermocycling conditions were as follows: $94^{\circ} \mathrm{C}$ for $2 \mathrm{~min}, 35$ cycles of $94^{\circ} \mathrm{C}$ for $30 \mathrm{~s}, 55^{\circ} \mathrm{C}$ for $30 \mathrm{~s}$, and $72^{\circ} \mathrm{C}$ for $45 \mathrm{~s}$; and a final cycle of $72^{\circ} \mathrm{C}$ for $7 \mathrm{~min}$.

\section{mRNA purification and ds cDNA synthesis analysis}

According to manufacturer protocols, $2 \mathrm{mg}$ total RNA from the fruits of seeded or seedless lichi (Litchi chinensis Sonn cv. Seedless) was used for mRNA extraction, respectively (PolyA Ttract mRNA Isolation Systems III, Promega), followed by reverse transcription, second-strand cDNA synthesis, and RsaI digestion (PCR-Select ${ }^{\mathrm{TM}}$ cDNA Subtraction Kit, Clontech).

All the above products were separated on a $1.2 \%$ agarose gel, stained with ethidium bromide, and photographed under UV light.

\section{RNA-Seq}

Using the Oligotex mRNA Mini Kit (Qiagen), mRNA samples were purified from $20 \mu \mathrm{g}$ total RNAs extracted from Cymbidium sinense, Neuwiedia veratrifolia, and Holcoglossum amesianum. The ds cDNAs were synthesized and then sequenced via Solexa according to the manufacturer protocols.

\section{RESULTS AND DISUSSION}

\section{RNA purity, integrity, and yield}

The $\mathrm{A}_{260} / \mathrm{A}_{280}$ ratio of the RNA samples ranged from 1.9 to 2.3, and the $\mathrm{A}_{260} / \mathrm{A}_{230}$ ratio 
was above 4.0 for each of the samples, which suggested minimum contaminants of salts, proteins, polyphenolics, or polysaccharides. The RNA yields were in the range of 20 to 300 $\mu \mathrm{g} / \mathrm{g}$ (Table 1). The formaldehyde denaturing gel-electrophoresis results showed distinct $28 \mathrm{~S}, 26 \mathrm{~S}, 25 \mathrm{~S}, 23 \mathrm{~S}, 18 \mathrm{~S}$, and $16 \mathrm{~S}$ rRNA bands. The respective intensities of the $28 \mathrm{~S}, 26 \mathrm{~S}$, $25 \mathrm{~S}$, and $23 \mathrm{~S}$ rRNA bands were 1.5 to 2 times that of the corresponding $18 \mathrm{~S}$ or $16 \mathrm{~S}$ rRNA bands, which implies high RNA integrity (Figures 1, 2, and 3). Additionally, there were no visible bands around the loading wells, which indicates no genomic DNA contamination (Figures 1 and 2). The NanoDrop test showed the 25S/18S rRNA ratio for $H$. amesianum RC, $N$. veratrifolia, and $C$. sinense SW to be $1.9,1.4$ and 2.1, respectively. The respective RNA integrity number (RIN) was 7.6, 7.1, and 8.4 (Table 2). The NanoDrop test results indicated that the RNAs were qualified for RNA-Seq.

\begin{tabular}{|c|c|c|c|c|c|}
\hline Families & Genera & Plant species & Tissues & $\begin{array}{c}\text { Purity } \\
\left(\mathrm{A}_{260 / 280}\right)\end{array}$ & $\begin{array}{r}\text { Yield } \\
(\mu \mathrm{g} / \mathrm{g})\end{array}$ \\
\hline \multirow[t]{5}{*}{ Sapindaceae } & \multirow[t]{5}{*}{ Litchi } & \multirow[t]{5}{*}{ Litchi chinensis Sonn cv. Seedless } & Young seedless fruit & 2.15 & 330 \\
\hline & & & Young seeded fruit & 2.18 & 320 \\
\hline & & & Seedless fruit embryo & 2.08 & 340 \\
\hline & & & Seeded fruit embryo & 2.23 & 306 \\
\hline & & & Young leaf & 2.14 & 221 \\
\hline \multirow[t]{3}{*}{ Musaceae } & \multirow[t]{3}{*}{ Musa } & \multirow[t]{3}{*}{ Musa nana Lour. } & Young leaf & 2.03 & 165 \\
\hline & & & Ripening pulp & 2.14 & 232 \\
\hline & & & Mature pulp & 2.13 & 20 \\
\hline Pinaceae & Pinus & Pinus massoniana Lamb. & Shoot tip, needle & 2.14 & 213 \\
\hline Malvaceae & Gossypium & Gossypium hirsutum L. & Young leaf & 2.11 & 220 \\
\hline Solanaceae & Nicotiana & Nicotiana tabacum L. & Young leaf & 2.01 & 254 \\
\hline Gramineae & phyllostachys & Phyllostachys pubescens & Young leaf & 2.12 & 231 \\
\hline \multirow[t]{2}{*}{ Anacardiaceae } & \multirow[t]{2}{*}{ Mangifera } & \multirow[t]{2}{*}{ Mangifera indica $\mathrm{L}$. } & Young shoot tip & 2.19 & 276 \\
\hline & & & Young leaf & 2.18 & 227 \\
\hline Leguminosae & Cercis & Cercis chinensis Bge. & Expanded flower & 1.97 & 40 \\
\hline Amaryllidaceae & Agave & Agave sisalana Perrine. & Fleshy stem & 2.09 & 221 \\
\hline Liliaceae & Allium & Allium sativum L. & Fleshy bulb & 2.03 & 214 \\
\hline Zingiberaceae & Zingiber & Zingiber officinale Rosc. & Fleshy rhizome & 2.21 & 236 \\
\hline Orchidaceae & Cymbidium & Cymbidium goeringii Rchb.f. & Unexpanded flower & 2.17 & 234 \\
\hline Leguminosae & Glycine & Glycine $\max \mathrm{L}$ & Ripe fruit & 1.93 & 273 \\
\hline Commelinaceae & Zebrina & Zebrina pendula Schnizl cv. Quadricolor & Young leaf & 2.20 & 221 \\
\hline Taxodiaceae & Metasequoia & Metasequoia glyptostroboides $\mathrm{Hu}$ et Cheng & Young leaf & 2.10 & 243 \\
\hline
\end{tabular}

\section{cDNA synthesis}

We also demonstrated that the total RNAs prepared in large or small scale were qualified for mRNA extraction, $3^{\prime}$ cDNA ends amplification, and RT-PCR. Figure 4 shows that the litchi ds cDNA smeared from $0.3 \mathrm{~kb}$ to the gel wells and the digested ds cDNA mainly ranged from 0.1 to $2 \mathrm{~kb}$, which indicates excellent RNA quality and suitability for subtractive cDNA library construction. On the one hand, using specific paired primers for the $p s b \mathrm{~A}$ and Actin 1 genes, amplicons of the expected size were amplified (Figure 5). On the other hand, using the Actin 1 gene-specific 5' primer and anchor $3^{\prime}$ primer, the 3' cDNA ends were also successfully amplified, which showed that the obtained RNAs were efficiently reverse-transcribed into cDNA (Figure 5). 


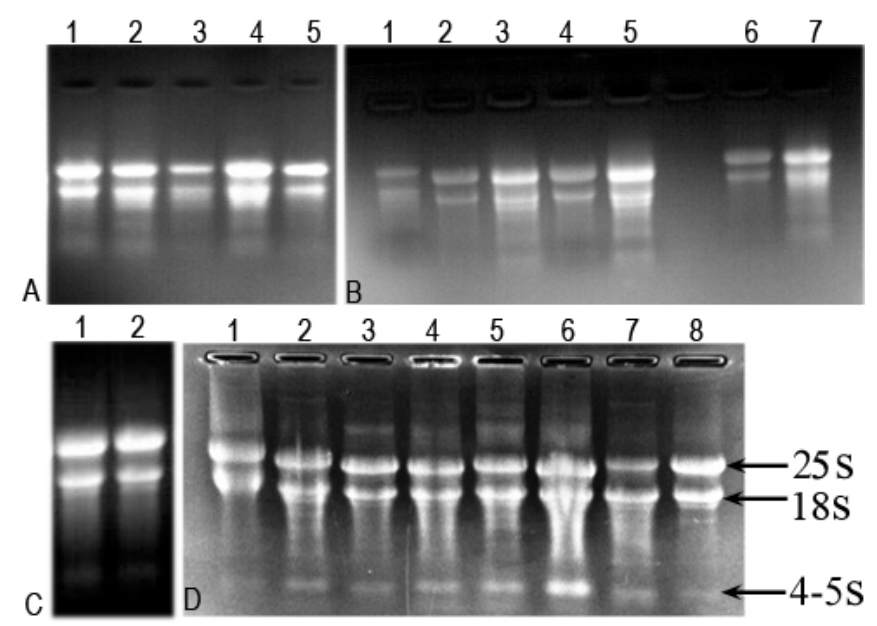

Figure 1. RNA isolated from different plant species tissues. A. Lanes 1 to $5=$ RNA extracts of young seeded fruit, seedless fruit, young leaf, seeded fruit embryo, seedless fruit embryo from Litchi chinensis Sonn cv. Seedless. Materials were collected 3 weeks after the female flower's expanding; B. Lane 1 = ripe and soft Musa nana Lour. pulp; lane 2= young M. nana Lour. pulp; lane 3 = young $M$. nana Lour. leaf; lane 4 = young Pinus massoniana Lamb. needle and young green shoot tip; lane 5 = young Nicotiana tabacum L. leaf; lane $6=$ Cercis chinensis Bge flower (the first fully expanded flower from apical meristem); lane 7 = young leaf of Gossypium hirsutum L. C. Lane 1 = young Phyllostachys pubescens leaf; lane 2 = young Zebrina pendula Schnizl cv. Quadricolor leaf. D. Lane 1 = ripe Glycine max L. seed; lane 2=Allium sativum L. bulb; lane 3 = first fully developed but unexpanded flower from Cymbidium goeringii Rchb.f; lane 4 = young Mangifera indica $\mathrm{L}$. shoot tip; lane 5 = young $M$. indica L. leaf; lane $6=$ young Zingiber officinale Rosc. rhizome; lane $7=$ young Agave sisalana Perrine flesh stem; lane $8=$ green young Metasequoia glyptostroboides Hu et Cheng leaf. Arrows showed ribosomal RNA different size.

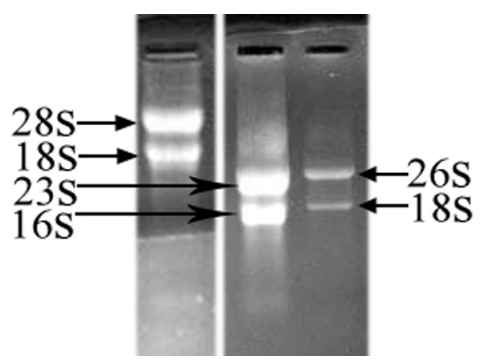

Figure 2. RNA from HELA, Escherichia coli Dh5a; Saccharomyces cerivisiae. Y190 cells. From left to right, RNA obtained from HELA a, E. coli Dh5 $\alpha$; S. cerivisiae Y190 cells. Arrows showed ribosomal RNA different size.

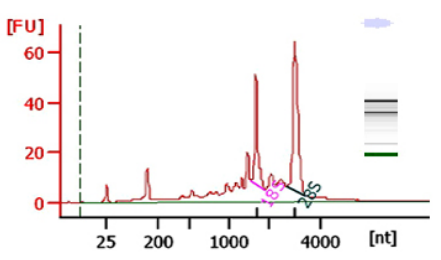

A

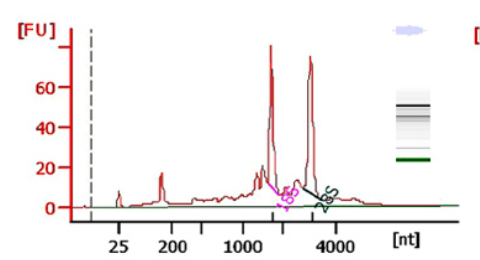

B

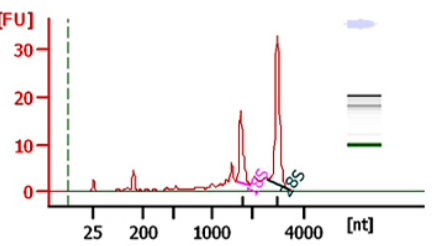

$\mathrm{C}$

Figure 3. RNA integrity judged by Nano drop test. A. RNA extracts of Holcoglossum amesianum RC young leaf. B. RNA extracts of Neuwiedia veratrifolia young leaf. C. RNA extracts of Cymbidium SW young leaf. 
Table 2. NanoDrop test used to evaluate plant RNA integrity.

\begin{tabular}{llcc}
\hline Genera & Plant species & rRNA Ratio25s/18s & RNA integrity number \\
\hline Holcoglossum & Holcoglossum amesianum RC & 1.9 & 7.6 \\
Neuwiedia & Neuwiedia veratrifolia & 1.4 & 7.1 \\
Cymbidium & Cymbidium SW & 2.1 & 8.4 \\
\hline
\end{tabular}

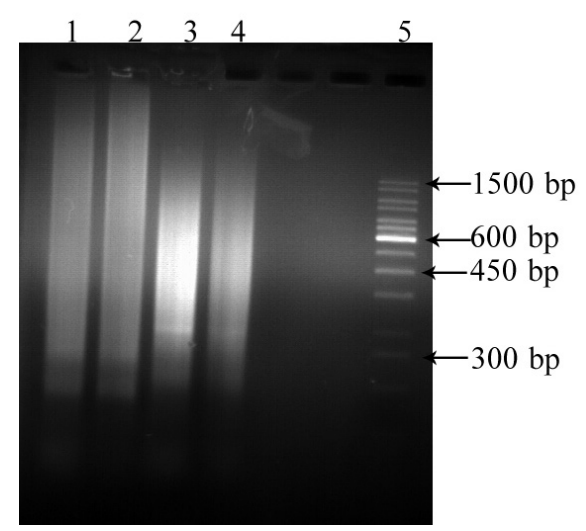

Figure 4. mRNA purification and ds cDNA synthesis and RsaI digestion analysis. Lane $1=\mathrm{ds}$ cDNA generated with mRNA purified from young Litchi seeded fruit RNA. Lane $2=\mathrm{ds}$ cDNA generated with mRNA purified from young Litchi seedless fruit RNA. Lane $3=\mathrm{ds}$ cDNA of young Litchi seeded fruit digested by RsaI. Lane $4=\mathrm{ds}$ cDNA of young Litchi seedless fruit digested by RsaI. Lane $5=50$ bp DNA marker (TaKaRa, China).

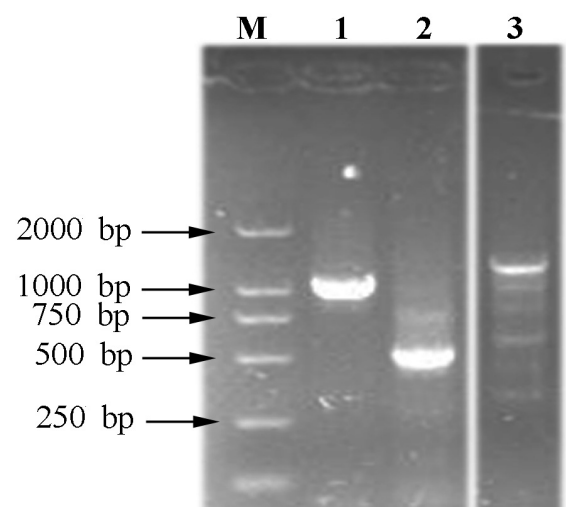

Figure 5. RT-PCR product analysis through agarose gel electrophoresis. Agarose gels electrophoresis analyze RT-PCR product from total RNA. Lane $M=$ DL 2000 DNA marker (TaKaRa, China). Lane 1=1020-bp RT-PCR amplicon of gene psbA (RNA purified from Mangifera indica $\mathrm{L}$. young leaf). Lane $2=500$-bp amplicon of Actin1 gene amplified with specific primers (RNA isolated from $M$. indica L. young shoot tip). Lane 3 = approximately 1000-bp amplicons of Actin1 gene amplified with 5' specific primer and 3'anchor primer (RNA obtained from M. indica L. young shoot tip).

\section{RNA-Seq}

The total reads were $16,000,000$ and the total nucleotides were $1,200,000,000 \mathrm{nt}$ for 
each of the RNA samples. The respective Q20 scores for H. amesianum RC, $N$. veratrifoli, and $C$. sinense SW were $88.82,84.31$, and $90.23 \%$, which demonstrates excellent sequence quality (Table 3).

\section{Table 3. RNA-Seq via solexa.}

\begin{tabular}{lccccc}
\hline Samples & Total reads & Total nucleotides $(\mathrm{nt})$ & Q20 (\%) & N (\%) & GC (\%) \\
\hline Holcoglossum amesianum RC & $16,000,000$ & $1,200,000,000$ & 88.82 & 0.09 & 48.29 \\
Neuwiedia veratrifoli & $16,000,000$ & $1,200,000,000$ & 84.31 & 0.06 & 44.45 \\
Cymbidium SW & $16,000,000$ & $1,200,000,000$ & 90.23 & 0.06 & 47.37 \\
\hline
\end{tabular}

\section{Comparison of RNA with guanidinium thiocyanate method}

Generally, highly intact RNAs can be isolated from mammalian cells and animal tissues through the acid-guanidinium thiocyanate-phenol-chloroform method (Figure 6A). However, when we applied it to the lichi leaf and mango shoot tip, the homogenates and the subsequently precipitated RNA pellets became brown and extremely viscous, which suggests severe contamination by polysaccharides and oxidized polyphenols. On the contrary, our purification method rendered RNA of good quality from plant materials, but it failed in animal tissues (Figure 6B).

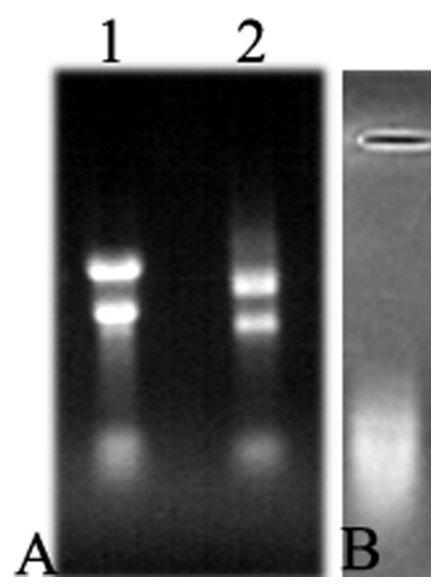

Figure 6. RNA purified from HELA cells and mouse liver using different methods. A. Guanidinium thiocyanatephenol-chloroform extraction method. Lane $1=$ RNA of HeLa cells. Lane 2 = RNA of mouse liver tissues. B. our method. RNA of mouse liver.

Through this procedure, we successfully purified high-quality RNAs from materials representing 18 plant families, including nutrition storage tissues such as seeds, fruits, tubers, fleshy stems, and flowers that contain a large amount of proteins, lipids, polysaccharides, and secondary metabolites. In particular, the mature flower petal and the succulent ripe banana pulp (the peel was completely yellow and scattered with speckles) have extremely abundant polysaccharides. Moreover, the cotton leaf, litchi leaf, purple dayflower leaf, pine needle and shoot tip, orchid flower, ginger rhizome (purchased from a market), and garlic bulb (stored 
for several months at room temperature, purchased from a market) carry a great variety of secondary metabolites. The biochemical compositions differ greatly among these materials, and most of the tissues listed in Table 1 are typically considered as recalcitrant materials for RNA isolation (Loomis, 1974; Newbury and Possingham, 1977; Katterman and Shattuck, 1983; Chang et al., 1993; Gehrig et al., 2000; Kiefer et al., 2000). Apart from plant materials, we also accomplished RNA isolation from mammalian cells (HeLa), and yeast (S. cerivisiae Y190) and bacterial (E. coli Dh5 $)$ cells.

Integrating several reported methods, this procedure demonstrates the following characteristics contributing to the successful RNA isolation. First, the homogenization solution, which contains $\mathrm{CTAB}, \mathrm{NaCl}$, and $\beta$-mercaptoethanol, can efficiently restrain RNase and polyphenols oxidase activities and inhibit polysaccharides and secondary metabolites from combining with nucleic acids (Fang et al., 1992; Ildiko et al., 1999). Then, simply through centrifugation and selective precipitation by $\mathrm{LiCl}$, most of the cell debris, polyphenols, polysaccharides, proteins, DNA fragments, and other contaminants are left in the supernatant (Ainsworth, 1994; Mehar et al., 2000). Finally, the RNA pellet is suspended in denaturing solution and re-precipitated with ethanol. With these treatments, high-quality RNAs are eventually purified.

The main significance of this simple procedure is that it can be readily applied to a wide range of plant species and tissues, in contrast to other reported methods (as pointed out in the Introduction). Moreover, in most of cases, no organic extraction is required, and the RNAs are still excellent for downstream applications. In conclusion, this method is a versatile procedure suitable for RNA isolation from plant tissues, as well as from mammalian, bacterial, and yeast cells.

\section{ACKNOWLEDGEMENTS}

Research supported by funding to L.Q. Huang, in part from Shenzhen City for Upgrading of the Shenzhen Key Laboratory of Gene and Antibody Therapy and for Building of the State Key Laboratory of Health Science and Technology.

\section{REFERENCES}

Ainsworth C (1994). Isolation of RNA from floral tissue of Rumex acetosa (Sorrel). Plant Mol. Biol. Rep. 12: 198-203.

Almarza J, Morales S, Rincon L and Brito F (2006). Urea as the only inactivator of RNase for extraction of total RNA from plant and animal tissues. Anal. Biochem. 358: 143-145.

Chang S, Puryear J and Caimey J (1993). A simple and efficient method for isolating RNA from pine trees. Plant Mol. Biol. Rep. 11: 113-116.

Chomczynski P and Sacchi N (1987). Single-step method of RNA isolation by acid guanidinium thiocyanate-phenolchloroform extraction. Anal. Biochem. 162: 156-159.

Chomczynski P and Sacchi N (2006). The single-step method of RNA isolation by acid guanidinium thiocyanate-phenolchloroform extraction: twenty-something years on. Nat. Protoc. 1: 581-585.

Fang G, Hammar S and Grumet R (1992). A quick and inexpensive method for removing polysaccharides from plant genomic DNA. Biotechniques 13: 52-4, 56.

Gehrig HH, Winter K, Cushman J, Borland A, et al. (2000). An improved RNA isolation method for succulent plant species rich in polyphenols and polysaccharides. Plant Mol. Biol. Rep. 18: 369-376.

Geuna F, Hartings H and Scienza A (1998). A new method for rapid extraction of high quality RNA from recalcitrant tissues of grapevine. Plant Mol. Biol. Rep. 16: 61-67.

Ildiko B, Jan-Peter N and Mlynarova L (1999). Isolation of high quality DNA and RNA from leaves of the carnivorous plant Drosera rotundifolia. Plant Mol. Biol. Rep. 17: 269-277.

Katterman FR and Shattuck VI (1983). An effective method of DNA isolation from the mature leaves of Gossypium 
species that contain large amounts of phenolic terpenoids and tannins. Prep. Biochem. 13: 347-359.

Khanuja SPS, Shasany AK and Darokar MP (1999). Rapid isolation of DNA from dry and fresh samples of plants producing large amounts of secondary metabolites and essential oils. Plant Mol. Biol. Rep. 17: 1-7.

Kiefer E, Heller W and Ernst D (2000). A simple and efficient protocol for isolation of functional RNA from plant tissues rich in secondary metabolites. Plant Mol. Biol. Rep. 18: 33-39.

Levi A, Galau GA and Wetzstein HY (1992). A rapid procedure for the isolation of RNA from high-phenolic-containing tissues of pecan. Hort. Sci. 27: 1316-1318.

Li B, Wang B, Tang K, Liang Y, et al. (2006). A simple and convenient approach for isolating RNA from highly viscous plant tissue rich in polysaccharides. Colloids Surf. B Biointerfaces 49: 101-105.

Loomis WD (1974). Overcoming problems of phenolics and quinones in the isolation of plant enzymes and organelles. Methods Enzymol. 31: 528-544.

Mehar HA, Dhawan P and Nath P (2000). A Simple Procedure for the Isolation of High Quality RNA from Ripening Banana Fruit. Plant Mol. Biol. Rep. 18: 109-115.

Newbury HJ and Possingham JV (1977). Factors affecting the extraction of intact ribonucleic Acid from plant tissues containing interfering phenolic compounds. Plant Physiol. 60: 543-547.

Puissant C and Houdebine LM (1990). An improvement of the single-step method of RNA isolation by acid guanidinium thiocyanate-phenol-chloroform extraction. Biotechniques 8: 148-149.

Sambrook J, Fritsch EF and Maniatis T (1989). Molecular Cloning: A Laboratory Manual. Cold Spring Harbor

Sharma AD, Gill PK and Singh P (2003). RNA isolation from plant tissues rich in polysaccharides. Anal. Biochem. 314: 319-321.

Wan CY and Wilkins TA (1994). A modified hot borate method significantly enhances the yield of high-quality RNA from cotton (Gossypium hirsutum L.). Anal. Biochem. 223: 7-12.

Weishing K, Nybom H, Wolff K and Meyer W (1995). DNA Isolation and Purification. DNA Fingerprinting in Plants and Fungi. CRC Press, Boca Raton. 